\title{
Malatya yöresi mahalli güzlük armut genotiplerinin seleksiyonu
}

\author{
Yusuf BAYINDIR1, Erdoğan ÇöÇEN¹, Tahir MACiT², Nedim GÜLTEKIN1, Ebru TOPRAK ÖZCAN³, Ahmet \\ ASLAN ${ }^{1}$, Rafet ASLANTAŞ ${ }^{4}$
}

\author{
${ }^{1}$ Kayısı Araştırma Enstitüsü Müdürlügü, MALATYA \\ 2Malatya Gıda Tarım ve Hayvancılık İl Müdürlüğü, MALATYA \\ ${ }^{3}$ Manisa Bağcllık Araştırma Enstitüsü Müdürlüğü, MANíSA \\ 4Eskișehir Osmangazi Üniversitesi, Ziraat Fakültesi, Bahçe Bitkileri Bölümü, ESKIŞ̦HİR
}

Alınış tarihi: 23 Ocak 2018, Kabul tarihi: 04 Nisan 2018

Sorumlu yazar: Yusuf BAYINDIR, e-posta:ybayindir802@hotmail.com

Öz

Bu çalışma 2014-2017 yılları arasında Malatya ilinde yetiştiriciliği yapılan mahalli güzlük armut genotiplerinin seleksiyonu amacıyla yürütülmüștür. Çalışma kapsamında gerçekleştirilen arazi taramalarında ön seleksiyonla meyve kalitesi yüksek, verimli ve sağlıklı ağaçlar işaretlenmiş ve iki yıl süreyle bu ağaçlardan rastgele alınan meyve örneklerinde pomolojik ve duyusal analizler gerçekleştirilmiştir. Elde edilen veriler değiştirilmiş tartılı derecelendirme metoduyla değerlendirilmiştir. Değerlendirme sonunda on bir genotip (44.02.03, 44.05.02, 44.02.15, 44.02.07, $44.02 .04,44.02 .05,44.06 .15,44.07 .07,44.02 .11$, 44.11.19, 44.11.05) ümitvar olarak belirlenmiştir. Ümitvar genotiplerde meyve ağırlığı 109.21 (44.02.04) - 197.65 g (44.02.07), meyve eti sertliği 3.95 (44.06.15) - $6.94 \mathrm{~kg} / \mathrm{cm}^{2}$ (44.11.19), suda çözünebilir kuru madde (SÇKM) oranı ise \% 13.25 (44.11.19) - 17.97 (44.02.04) arasında değişmiştir. Ümitvar genotiplerin yedi adedinin meyvelerinin kumsuz (44.02.03, 44.02. 07, 44.02.04, 44.02.05, $44.02 .11,44.06 .15,44.11 .04)$, dört adedinin orta derecede kumlu $(44.02 .15,44.05 .02$, 44.07.07, 44.11.19) olduğu belirlenmiştir. Ümitvar genotiplerin sekiz adedinin yeme kalitesinin iyi (44.02.03, 44.02.07, 44.02.15, 44.05.02, 44.02.04, $44.06 .15,44.11 .19,44.11 .04)$, üç adedinin (44.02.05, $44.02 .11,44.07 .07)$ ise orta kalitede olduğu belirlenmiştir. Çalışma sonunda ümitvar olarak belirlenen genotipler, seleksiyonun ikinci aşamasında materyal olarak kullanılmak ve genetik kaynakların muhafazası amacıyla koleksiyon bahçesine aktarılmıştır.

Anahtar kelimeler: Armut, mahalli çeşit, pomoloji, tartılı derecelendirme metodu

Selection of local autumn pear genotypes in Malatya region

\section{Abstract}

This study was conducted between 2014 and 2017 to select local genotypes of autumn pear cultivated in Malatya province, Turkey. In the field surveys conducted within the scope of the study, with preselection studies, the determined trees, having high fruit quality, fruitful and healthy, were marked and pomological and sensory analysis were carried out in the fruit samples randomly taken from the trees for two years. The data obtained were evaluated using the modified weighed rating method. At the end of the evaluation, eleven genotypes $(44.02 .03,44.05 .02$, $44.02 .15,44.02 .07,44.02 .04,44.02 .05,44.06 .15$, $44.07 .07,44.02 .11,44.11 .19,44.11 .05)$ were identified as promising. The fruit weight of the promising genotypes was between 109.21 (44.02.04) and $197.65 \mathrm{~g}$ (44.02.07), the fruit flesh hardness was $3.95(44.06 .15)-6.94 \mathrm{~kg} / \mathrm{cm}^{2}$ (44.11.19) and the TSS ratios were between $13.25 \%$ (44.11.19) and $17.97 \%$ (44.02.04). In terms of grittiness, seven $(44.02 .03,44.02 .07,44.02 .04$, $44.02 .05,44.02 .11,44.06 .15,44.11 .04)$ of the promising genotypes were not gritty, whereas four (44.02.15, 44.05.02, 44.07.07, 44.11.19) had medium 
grittiness. It was determined that eating quality was good in eight $(44.02 .03,44.02 .07,44.02 .15,44.05 .02$, $44.02 .04,44.06 .15,44.11 .19,44.11 .04)$ of the promising genotypes, and it was medium quality in three $(44.02 .05,44.02 .11,44.07 .07)$ of the genotypes. At the end of the study, the promising genotypes was transferred to the collection orchard to use as material in the second stage of selection and the conservation of genetic resources.

Key words: Pear, local variety, pomology, weighted ranked method

\section{Giriş}

Yumuşak çekirdekli meyve türlerinden birisi olan armut (Pyrus communis L.), elmadan sonra dünya üzerinde en fazla kültürü yapılan meyve türüdür. Dünya üzerinde Doğu Avrupa'dan Kafkasya'ya ve Türkistan'a kadar geniş bir bölgede yayılış gösteren bu meyve türünün asıl gen merkezlerinden birisi de Anadolu'dur. Öyle ki, Anadolu'da 600'den fazla armut çeşidinin olduğu bildirilmektedir (Özbek, 1978; Büyükyılmaz ve ark., 1994; Özçagıran ve ark., 2004). Türkiye sahip olduğu ekolojik avantajlar nedeniyle pek çok meyve tür ve çeşidinin gen merkezi konumundadır. Çok sayıda meyve tür ve çeşidinin oluşturduğu bu genetik zenginlik, farklı toprak ve iklim koşullarına uygun çeşit ıslahı, farklı iç ve dış pazar taleplerine uygun çeşit geliştirme açısından alternatifler oluşturmaktadır (Bostan, 2009). Dünya armut üretim istatistikleri incelendiğinde 27.345.929 tonluk toplam üretim miktarının \% 70.9'luk kısmını tek başına Çin'in (19.388.063 ton) gerçekleștirdiği görülmektedir. Çin'i \% 3.3'lük oranla (905.605 ton) Arjantin, \% 2.7'lik oranla ABD, \% 2.6 'llk oranla İtalya izlemektedir. Türkiye ise \% 1.7'lik payla (472.250 ton) dünya armut üretiminde beşinci sırada yer almaktadır (FAO, 2016). Anadolu'da standart ve tescilli çeşitlerin yanı sıra çok sayıda mahalli armut çeşidi de yetiștirilmektedir. Bu mahalli çeşitler farklı bir damak tadı sunmanın yanı sıra yeni çeşitlerin geliştirilmesinde önemli bir genetik kaynak oluşturmaktadır. Bostan ve Şen (1991), genellikle aile tüketimi ve yerel pazarlara hitap eden mahalli çeşitlerin ıslah çalışmaları için bulunmaz nitelikte materyal olduklarını bildirmektedir. Karlıdă̆ ve Eşitken (2006), ülkemizde bulunan mahalli meyve çeşitlerinin özelliklerinin belirlenerek koruma altına alınmasının gereğini vurgulamıştır. Armut ıslahına yönelik seleksiyon çalışmalarında meyve kalite özellikleri, erkencilik, soğuklara dayanım, düzenli ve yüksek verim ile hastalık ve zararlılara dayanıklılık, üzerinde durulan önemli özellikler arasında yer almaktadır (Özbek, 1947; Güleryüz, 1977; Özbek, 1978; Bostan ve Şen, 1991; Büyükyılmaz ve ark., 1992; Așkın ve Oğuz, 1995; Ünal ve ark., 1997; Demirsoy ve ark., 2007; Öztürk ve Demirsoy, 2013; Cevahir ve Bostan, 2017). Malatya kayısı üretimiyle ön plana çıkmakla birlikte, ikliminin uygun olmasıyla diğer birçok meyve türlerinin de üretiminin yapıldığı bir ildir. İlde birçok meyve türünde çok sayıda mahalli çeşide rastlamak mümkündür. Doğu Anadolu Bölgesi yukarı Fırat havzasında bulunan Malatya ilinde tescilli ve standart armut çeşitlerinin yanı sıra çok sayıda yerel armut çeşitleri de yetiştirilmektedir. Malatya ilinin önemli bir meyve üretim bölgesi olduğunu belirten Ülkümen (1938), Malatya ili Merkez ilçede dar bir alanda yaptığı çalışmada yörede mahalli olarak yetiştirilen 26 elma, 12 armut ve 6 kayısı çeşidi tespit etmiştir. Bu çalışmada; Malatya ili, ilçeleri ve köylerinde yöre halkı tarafından bilinen ve yetiştirilen mahalli güzlük armut genotiplerinin seleksiyonu amaçlanmıştır.

\section{Materyal ve Yöntem}

\section{Materyal}

Çalışmanın materyalini, Malatya ili, ilçeleri ve köylerinde yetiştirilen, yöre halkı tarafından bilinen, uzun yıllardır yetiştiriciliği yapılan mahalli güzlük armut genotipleri oluşturmuştur. 2014-2017 yılları arasında yürütülen çalışmada seleksiyonda meyve kalitesi yüksek genotiplerin seçimi hedeflenmiş olup, ağaçların belirlenmesinde verimli ve sağlıklı gelişme göstermelerine dikkat edilmiştir. Ön seleksiyonla tespit edilen genotiplere ait ağaçlardan tesadüfi olarak alınan onar adet meyve; fiziksel, kimyasal ve duyusal analizlerde kullanılmıştır.

\section{Yöntem}

Çalışma kapsamında ilk olarak arazi tarama programı hazırlanmış ve bu programa göre arazi taraması gerçekleştirilerek seleksiyon amacına uygun ağaçlar işaretlenmiştir. İşaretlenen ağaçlardan iki yıl süreyle rastgele alınan 10'ar adet meyve örneklerinde fiziksel, kimyasal ve duyusal analizler gerçekleştirilmiştir. Meyve eni, boyu, meyve sapı uzunluğu ve meyve sap çapı 0.01 mm'ye duyarlı dijital kumpas ile ölçülerek ortalama değerleri alınmıştır. Meyve eti sertliği el penetrometresi ile ölçülmüştür. Ölçümde $11.1 \mathrm{~mm}$ çapındaki penetrometre ucu kullanılmıştır. Ölçüm esnasında öncelikle penetrometre ucunun gireceği kadar alanın meyve kabuğu kaldırılarak et sertliği meyve etinde ölçülmüștür. Bulunan değerlerin 
ortalaması meyve eti sertliği olarak kaydedilmiştir. Meyve kabuk rengi ölçümleri ise her genotipten başlangıçta hasat edilen 10 meyvede; her meyvede iki okuma yapılarak ölçüm değerlerinin ortalamaları alınmıştır. Ölçümler 'Minolta Chromo Meter CR-400' cihazı kullanılarak L, a, b cinsinden belirlenmiştir. Genotiplerin meyve sapı şekli görsel olarak değerlendirilmiş; düz, eğik ve kıvrık şeklinde sınıflandırılmıştır. Meyvelerin katı meyve sıkacağında suyu çıkarılarak süzüldükten sonra elde edilen meyve sularında SÇKM, TEA ve pH ölçümleri yapılmıştır. Suda çözünür kuru madde miktarı ( $\%$ SÇKM) dijital el refraktometresi (ATAGO Pal-1) ile belirlenirken, $\mathrm{pH}$ değeri ise elde edilen meyve suyunda pH metre ('WTW 82362 Weilheim İnolab pH 720) ile ölçülmüştür. Ölçüm esnasında, elektrotlar pH değeri sabitleninceye kadar örnek içerisinde yaklașı 1-2 dakika tutulmuștur (Cemeroğlu, 1992). Titre Edilebilir Asitlik (\% TEA) ölçümü, meyve suyunda fenol ftaleyn indikatörü yardımıyla $0.1 \mathrm{~N} \mathrm{NaOH}$ ile titre edilmiş ve sonuçlar malik asit cinsinden titrasyon metodu ile belirlenmiștir (Altan, 1989). Meyvelerin kumluluk durumu, tat ve yeme kalitesi beș kișiden olușan jüri tarafindan duyusal olarak 1-5 arasında puanlanmıştır. Verilerin Değerlendirilmesinde Michelson ve ark. (1958), tarafından önerilen ve Büyükyllmaz ve ark. $(1992 ; 1994)$ tarafından kullanılan yöntem uyarlanarak 'Değiştirilmiş Tartılı Derecelendirme Yöntemi' kullanılmıştır (Çizelge 1).
Çizelge 1. Tartılı derecelendirmede kullanılan kriterler, sinıflar, sinıf aralıkları ve puanları

\begin{tabular}{|c|c|c|c|c|}
\hline Kriterler & $\begin{array}{c}\text { Rölatif } \\
\text { Puanlar }\end{array}$ & Sinıflar & Sınıf Aralığı & Puan \\
\hline \multirow{3}{*}{$\begin{array}{c}\text { Meyve } \\
\text { Ağırlığı (g) }\end{array}$} & \multirow{3}{*}{30} & Küçük & $50.75-99.71$ & 1 \\
\hline & & Orta & $99.72-148.67$ & 2 \\
\hline & & İri & $148.67-197.65$ & 3 \\
\hline \multirow{3}{*}{ SÇKM (\%) } & \multirow{3}{*}{20} & Düşük & $8.60-11.79$ & 1 \\
\hline & & Orta & $11.80-14.99$ & 2 \\
\hline & & Yüksek & $15.00-18.20$ & 3 \\
\hline \multirow{3}{*}{$\begin{array}{c}\text { Yeme } \\
\text { Kalitesi }\end{array}$} & \multirow{3}{*}{15} & Kötü & $2.4<$ Puan & 1 \\
\hline & & Orta & $2.4 \leq$ Puan $\leq 3.6$ & 2 \\
\hline & & İyi & $3.6<$ Puan & 3 \\
\hline \multirow{3}{*}{$\begin{array}{c}\text { Meyve Eti } \\
\text { Sertliği } \\
\left(\mathrm{kg} / \mathrm{cm}^{2}\right)\end{array}$} & \multirow{3}{*}{15} & Yumuşak & $2.82-4.88$ & 1 \\
\hline & & Orta & $4.89-6.96$ & 2 \\
\hline & & Sert & $6.97-9.04$ & 3 \\
\hline \multirow{3}{*}{ Kumluluk } & \multirow{3}{*}{20} & Çok Kumlu & $2.4<$ Puan & 1 \\
\hline & & Orta Kumlu & $2.4 \leq$ Puan $\leq 3.6$ & 2 \\
\hline & & Kumsuz & $3.6<$ Puan & 3 \\
\hline
\end{tabular}

\section{Bulgular}

Çalışma Malatya ilinde yetiştiriciliği yapılan mahalli güzlük armut genotiplerinin seleksiyonu amaciyla yürütülmüştür. Çalışmada ilk olarak Malatya ili ve ilçelerinde arazi taraması gerçekleştirilmiş ve ön seleksiyonla meyve kalitesi yüksek, verimli ve sağlıklı olduğu gözlenen 20 güzlük armut genotipi işaretlenmiştir. Ön seleksiyonda meyve tadı kötü, aşırı kumlu ve kalitesiz meyvelere sahip ağaçlar çalışmaya dahil edilmemiştir. Ön seleksiyonda işaretlenen genotiplerin konum ve meyve hasat dönemine ait bilgiler Çizelge 2'de verilmiştir.

Çizelge 2. Belirlenen güzlük armutların konum bilgileri ve meyve hasat dönemleri

\begin{tabular}{|c|c|c|c|c|c|}
\hline Genotip No & İl & İlçe & Mevki & Rakım (m) & Hasat Dönemi \\
\hline 44.02 .03 & Malatya & Arapgir & Onar Köyü & 1206 & 13-20 Eylül \\
\hline 44.02 .04 & Malatya & Arapgir & Kayakesen Kozer Mezrası & 1282 & 10-15 Eylül \\
\hline 44.02 .05 & Malatya & Arapgir & Kayakesen Kozer Mezrası & 1289 & 5 - 11 Eylül \\
\hline 44.02 .06 & Malatya & Arapgir & Kayakesen Kozer Mezrası & 1292 & 5 -10 Eylül \\
\hline 44.02 .07 & Malatya & Arapgir & Budak Mah. & 1185 & 03 -10 Eylül \\
\hline 44.02 .11 & Malatya & Arapgir & Onar Köyü & 1206 & 27 Ağustos -7 Eylül \\
\hline 44.02 .12 & Malatya & Arapgir & Tepe Mevki & 1210 & 28 Ağustos - 7 Eylül \\
\hline 44.02 .15 & Malatya & Arapgir & Budak Mah. & 1167 & 5-15 Eylül \\
\hline 44.05 .02 & Malatya & Darende & Oklar Yazısı Çaybașı Köy & 1215 & 5-10 Eylül \\
\hline 44.06 .01 & Malatya & Doğanșehir & Güneydoğu Köyü & 1295 & 5-10 Eylül \\
\hline 44.06 .10 & Malatya & Doğanșehir & Yeni Mah. & 1246 & 5-10 Eylül \\
\hline 44.06 .11 & Malatya & Doğanșehir & Yeni Mah. & 1246 & 5-15 Eylül \\
\hline 44.06 .15 & Malatya & Doğanșehir & Sürgü & 1378 & 29 Ağustos - 7 Eylül \\
\hline 44.07 .07 & Malatya & Doğanyol & Minnetoğlu Çiftliği & 962 & 13-22 Eylül \\
\hline 44.07 .09 & Malatya & Doğanyol & Gümüşsu İlköğretim & 1136 & 5-15 Eylül \\
\hline 44.11 .04 & Malatya & Pütürge & Yazlıca Mevki & 880 & 5-15 Eylül \\
\hline 44.11 .05 & Malatya & Pütürge & Karataş Mevki & 1120 & 15-24 Eylül \\
\hline 44.11 .18 & Malatya & Pütürge & Üçyaka Mevki & 875 & 5-15 Eylül \\
\hline 44.11 .19 & Malatya & Pütürge & Üçyaka Mevki & 880 & 5-10 Eylül \\
\hline 44.12 .02 & Malatya & Yazıhan & Erecek İbocuk & 1601 & 10-15 Eylül \\
\hline
\end{tabular}

Çalışmada ön seleksiyonla belirlenen 20 farklı güzlük armut genotipine ait meyve örneklerinde iki yll gerçekleştirilmiştir. Elde edilen verilerin 'Tartılı Derecelendirme Metodu'yla değerlendirilmesi süreyle analizler gerçekleştirilmiştir. Analizler sonucunda ümitvar genotipler belirlenmiștir. meyveler hasat edildikten sonra bekletilmeden 
Güzlük armut genotiplerinde fiziksel ölçüm bulguları

Çalışmada genotiplerden alınan meyve örneklerinin fiziksel ölçüm değerlerinin iki yıllık ortalaması olarak; meyve ağırlı̆̆ı 50.75 (44.02.12)-197.65 g (44.02.07), meyve eni 44.45 (44.02.12)-71.50 mm (44.11.19) ve meyve boyu ise 45.05 (44.02.12)-94.25 mm (44.02.07) arasında değişmiştir. Ölçümlerde ortalama meyve sapı uzunluğu 23.89 (44.02.15)-
$61.74 \mathrm{~mm}$ (44.07.07), meyve sap çapı 1.97 (44.06.11)-3.59 mm (44.11.18) ve meyve eti sertliği ise 2.82 (44.07.09)-9.04 kg/ $\mathrm{cm}^{2}$ (44.02.12) arasında değişmiştir. Meyve kabuk rengi ölçümlerinde L renk değeri 38.56 (44.02.06)-55.13 (44.02.03), a renk değeri -10.45 (44.11.19)-5.97 (44.02.06) ve b renk değeri ise 16.34 (44.02.06)-25.59 (44.06.15) arasında değişmiştir (Çizelge 3).

Çizelge 3. Güzlük armut genotiplerinin fiziksel meyve özelliklerine ait iki yıllık ortalama değerler

\begin{tabular}{|c|c|c|c|c|c|c|c|c|c|}
\hline Genotip No & $\begin{array}{c}\text { Meyve } \\
\text { Ağırlığı (g) }\end{array}$ & $\begin{array}{l}\text { Meyve Eni } \\
(\mathrm{mm})\end{array}$ & $\begin{array}{c}\text { Meyve } \\
\text { Boyu (mm) }\end{array}$ & $\begin{array}{l}\text { Meyve Sap } \\
\text { Uzunluğu } \\
(\mathrm{mm})\end{array}$ & $\begin{array}{l}\text { Meyve Sap } \\
\text { Çapı (mm) }\end{array}$ & $\begin{array}{l}\text { Meyve Eti } \\
\text { Sertliği } \\
\left(\mathrm{kg} / \mathrm{cm}^{2}\right)\end{array}$ & $\mathrm{L}^{*}$ & $a^{*}$ & $b^{*}$ \\
\hline 44.02 .03 & 151.89 & 60.99 & 86.99 & 32.20 & 2.40 & 4.95 & 55.13 & -8.00 & 24.59 \\
\hline 44.02 .04 & 109.21 & 58.85 & 63.71 & 31.78 & 3.10 & 5.47 & 43.40 & 3.33 & 18.90 \\
\hline 44.02 .05 & 158.82 & 62.56 & 72.21 & 32.07 & 3.17 & 4.38 & 50.96 & -6.57 & 22.59 \\
\hline 44.02 .06 & 84.78 & 53.81 & 57.71 & 31.14 & 2.90 & 6.92 & 38.56 & 5.97 & 16.34 \\
\hline 44.02 .07 & 197.65 & 66.52 & 94.25 & 34.09 & 3.11 & 5.30 & 52.59 & -3.60 & 20.79 \\
\hline 44.02 .11 & 171.33 & 60.05 & 91.04 & 26.90 & 2.99 & 5.08 & 45.85 & -8.56 & 19.99 \\
\hline 44.02 .12 & 50.75 & 44.45 & 45.05 & 28.21 & 2.49 & 9.04 & 45.01 & -10.27 & 21.00 \\
\hline 44.02 .15 & 174.15 & 66.32 & 68.67 & 23.89 & 3.54 & 5.98 & 41.78 & -9.39 & 19.17 \\
\hline 44.05 .02 & 173.58 & 69.28 & 69.95 & 40.88 & 2.63 & 5.73 & 43.66 & -6.70 & 21.74 \\
\hline 44.06 .01 & 126.36 & 59.86 & 62.80 & 38.22 & 3.43 & 3.20 & 40.85 & -3.34 & 19.02 \\
\hline 44.06 .10 & 93.04 & 57.16 & 52.62 & 33.41 & 2.13 & 6.50 & 53.15 & -5.51 & 23.34 \\
\hline 44.06 .11 & 76.54 & 50.96 & 51.47 & 40.09 & 1.97 & 5.40 & 41.27 & -5.74 & 17.34 \\
\hline 44.06 .15 & 157.90 & 64.19 & 70.96 & 54.43 & 3.06 & 3.95 & 49.92 & -4.54 & 25.59 \\
\hline 44.07 .07 & 167.00 & 68.32 & 59.92 & 61.74 & 2.62 & 6.91 & 48.66 & -7.11 & 24.11 \\
\hline 44.07 .09 & 146.45 & 60.30 & 66.40 & 42.12 & 3.22 & 2.82 & 48.80 & -3.22 & 23.73 \\
\hline 44.11 .04 & 143.44 & 64.13 & 67.21 & 30.78 & 3.41 & 5.16 & 45.46 & -7.14 & 20.73 \\
\hline 44.11 .05 & 125.57 & 58.44 & 58.23 & 24.78 & 3.07 & 4.83 & 45.15 & -9.11 & 21.11 \\
\hline 44.11 .18 & 106.85 & 58.15 & 63.73 & 33.72 & 3.59 & 6.82 & 43.28 & -9.76 & 18.67 \\
\hline 44.11 .19 & 187.14 & 71.50 & 71.50 & 29.07 & 3.44 & 6.94 & 40.76 & -10.45 & 18.13 \\
\hline 44.12 .02 & 111.12 & 56.29 & 72.54 & 28.79 & 2.45 & 5.24 & 47.88 & -6.02 & 22.37 \\
\hline Ortalama & 135.68 & 60.61 & 67.35 & 34.92 & 2.94 & 5.53 & 46.11 & -5.79 & 20.96 \\
\hline Std & 39.10 & 6.31 & 12.26 & 9.20 & 0.46 & 1.39 & 4.51 & 4.12 & 2.48 \\
\hline
\end{tabular}

Çizelge 4. Güzlük armut genotiplerinin kimyasal özelliklerine ait iki yıllık ortalamalar

\begin{tabular}{cccc}
\hline Genotip No & SCKM (\%) & TEA (\%) & $\begin{array}{c}\text { Meyve Suyu } \\
\text { pH's }\end{array}$ \\
\hline 44.02 .03 & 15.94 & 0.36 & 4.10 \\
44.02 .04 & 17.97 & 0.21 & 4.59 \\
44.02 .05 & 17.30 & 0.47 & 3.74 \\
44.02 .06 & 18.10 & 0.25 & 4.34 \\
44.02 .07 & 13.50 & 0.21 & 4.27 \\
44.02 .11 & 14.15 & 0.36 & 3.93 \\
44.02 .12 & 16.70 & 0.23 & 4.43 \\
44.02 .15 & 15.00 & 0.78 & 3.62 \\
44.05 .02 & 16.20 & 0.18 & 4.64 \\
44.06 .01 & 18.20 & 0.70 & 3.81 \\
44.06 .10 & 13.45 & 0.15 & 4.81 \\
44.06 .11 & 8.60 & 0.17 & 4.47 \\
44.06 .15 & 14.70 & 0.09 & 4.93 \\
44.07 .07 & 17.30 & 0.33 & 3.86 \\
44.07 .09 & 17.00 & 0.31 & 4.25 \\
44.11 .04 & 15.85 & 0.30 & 4.40 \\
44.11 .05 & 16.37 & 0.29 & 4.57 \\
44.11 .18 & 14.70 & 0.52 & 3.92 \\
44.11 .19 & 13.25 & 0.15 & 4.73 \\
44.12 .02 & 13.95 & 0.25 & 4.19 \\
\hline Ortalama & 15.41 & 0.32 & 4.28 \\
\hline Std & 2.16 & 0.17 & 0.36 \\
\hline
\end{tabular}

Güzlük armut genotiplerinde kimyasal ölçüm bulguları

Meyve örneklerine ait meyve suyunda gerçekleştirilen ölçümlerde SÇKM değeri \% 8.60 (44.06.11) ile \% $18.20 \quad$ (44.06.01), malik asit cinsinden titre edilebilir asit değeri \% 0.09 (44.06.15) ile \% 0.78 (44.02.15), meyve suyu pH'sı ise 3.62 (44.02.15) ile 4.93 (44.06.15) arasinda değişmiştir (Çizelge 4).

\section{Güzlük armut genotiplerinin duyusal meyve özelliklerine ait bulgular}

Çalışma kapsamında incelenen genotiplerin meyve sap şekli, kumluluk durumu, tat ve yeme kalitesine ait veriler Çizelge 5 ' te verilmiştir. Yapılan çalışmada meyve sap şeklinin 5 genotipte $(44.02 .04,44.02 .12$, $44.02 .15,44.06 .11,44.11 .18)$ düz, 9 genotipte (44.02.05, 44.02.06, 44.02.07, 44.02.11, 44.06.01, $44.07 .07,44.11 .05,44.11 .19,44.12 .02)$ eğik ve 6 genotipte ise $(44.02 .03,44.05 .02,44.06 .10,44.06 .15$, 44.07.09, 44.11.04) kıvrık olduğu görülmüştür. 
Çizelge 5. Güzlük armut genotiplerinin duyusal meyve özellikleri

\begin{tabular}{|c|c|c|c|c|}
\hline $\begin{array}{c}\text { Genotip } \\
\text { No }\end{array}$ & $\begin{array}{l}\text { Meyve Sapı } \\
\text { Şekli }\end{array}$ & $\begin{array}{l}\text { Kumluluk } \\
\text { Durumu }\end{array}$ & $\begin{array}{c}\text { Tat } \\
\text { Durumu }\end{array}$ & $\begin{array}{l}\text { Yeme } \\
\text { Kalitesi }\end{array}$ \\
\hline 44.02 .03 & Kivrık & Kumsuz & İyi & İyi \\
\hline 44.02 .04 & Düz & Kumsuz & İyi & İyi \\
\hline 44.02 .05 & Eğik & Kumsuz & Orta & Orta \\
\hline 44.02 .06 & Eğik & Kumsuz & İyi & Orta \\
\hline 44.02 .07 & Eğik & Kumsuz & İyi & İyi \\
\hline 44.02 .11 & Eğik & Kumsuz & Orta & Orta \\
\hline 44.02 .12 & Düz & Kumsuz & Orta & Orta \\
\hline 44.02 .15 & Düz & Orta Kumlu & Orta & İyi \\
\hline 44.05 .02 & Kıvrık & Orta Kumlu & Çok İyi & İyi \\
\hline 44.06 .01 & Eğik & Orta Kumlu & Orta & Orta \\
\hline 44.06 .10 & Kıvrık & Orta Kumlu & Orta & Orta \\
\hline 44.06 .11 & Düz & Orta Kumlu & İyi & İyi \\
\hline 44.06 .15 & Kivrık & Kumsuz & İyi & İyi \\
\hline 44.07 .07 & Eğik & Orta Kumlu & Orta & Orta \\
\hline 44.07.09 & Kıvrık & Orta Kumlu & Orta & Orta \\
\hline 44.11 .04 & Kıvrık & Orta Kumlu & Orta & İyi \\
\hline 44.11 .05 & Eğik & Kumsuz & İyi & İyi \\
\hline 44.11 .18 & Düz & Orta Kumlu & İyi & İyi \\
\hline 44.11 .19 & Eğik & Orta Kumlu & İyi & İyi \\
\hline 44.12.02 & Eğik & Orta Kumlu & Orta & Orta \\
\hline $\begin{array}{l}\text { Kumluluk } \\
\text { (44.02.03, } \\
\text { 44.02.11, } \\
\text { genotipin } \\
\text { 44.06.11, } \\
\text { 44.11.19, } \\
\text { edilmiştir. } \\
\text { 44.02.11, }\end{array}$ & $\begin{array}{c}\text { durumu } \\
44.02 .04, \\
44.02 .12,4 \\
(44.02 .15, \\
44.07 .07, \\
44.12 .02) \\
\text { Meyve ta } \\
44.02 .12,\end{array}$ & $\begin{array}{l}\text { bakımında } \\
44.02 .05,4 \\
44.06 .15,44.1 \\
44.05 .02,4 \\
44.07 .09,4 \\
\text { orta kum } \\
\text { tadının } 10 \text { ge } \\
44.02 .15,4\end{array}$ & $\begin{array}{l}\mathrm{n} 9 \mathrm{~g} \\
4.02 .06, \\
1.05) \mathrm{kur} \\
4.06 .01, \\
4.11 .04, \\
\text { u olduğ } \\
\text { notipte ( } \\
4.06 .01,\end{array}$ & $\begin{array}{l}\text { senotipin } \\
44.02 .07 \\
\text { msuz, } 11 \\
44.06 .10, \\
44.11 .18, \\
\text { u tespit } \\
44.02 .05\end{array}$ \\
\hline
\end{tabular}

44.07.07, 44.07.09, 44.11.04, 44.12.02) orta, 9 genotipte $(44.02 .03,44.02 .04,44.02 .06,44.02 .07$, 44.06.11, 44.06.15, 44.11.05, 44.11.18, 44.11.19) iуi ve 1 genotipte ise (44.05.02) çok iyi olduğu belirlenmiştir. Yeme kalitesinin 9 genotipte (44.02.05, 44.02.06, 44.02.11, 44.02.12, 44.06.01, $44.06 .10,44.07 .07,44.07 .09,44.12 .02)$ orta, 11 genotipte ise $(44.02 .03,44.02 .04,44.02 .07,44.02 .15$, 44.05.02, 44.06.11, 44.06.15, 44.11.04, 44.11.05, $44.11 .18,44.11 .19$ ) iyi olduğu belirlenmiştir.

Güzlük armut genotiplerinin tartılı derecelendirme puanları

Çalışma kapsamında elde edilen verilerin tartılı derecelendirmesinde genotiplerin aldıkları toplam puanlar 165 (44.06.11) ile 285 (44.02.03) arasında değişmiştir. Yapılan değerlendirmede 240 ve üzeri puan alan 11 genotip (44.02.03, 44.02.07, 44.02.15, 44.05.02, 44.02.04, 44.02.05, 44.02.11, 44.06.15, 44.0.707, 44.11.19, 44.11.04) ümitvar olarak belirlenmiştir (Çizelge 6).

Seleksiyonda ümitvar olarak belirlenen genotiplerin meyve özellikleri

Seleksiyonda ümitvar olarak belirlenen genotiplerin fiziksel meyve özelliklerinden meyve ağırlığı 109.21 (44.02.04)-197.65 g (44.02.07), meyve eni 58.44 (44.11.05)-71.50 mm (44.11.19), meyve boyu 58.23 (44.11.05)-94.25 mm (44.02.07), meyve sapı uzunluğu 23.89 (44.02.15)-61.74 mm (44.070.7), meyve sap çapı 2.40 (44.02.03)-3.54 mm (44.02.15) ve meyve eti sertliği ise 3.95 (44.06.15)-6.94 kg/ $\mathrm{cm}^{2}$ (44.11.19) arasında değişmiştir (Çizelge 7).

Çizelge 6. Genotiplerin tartılı derecelendirme puanları

\begin{tabular}{|c|c|c|c|c|c|c|}
\hline Genotip No & $\begin{array}{c}\text { Meyve Ağırlığı } \\
\text { Puanı }\end{array}$ & SÇKM Puanı & $\begin{array}{c}\text { Yeme Kalitesi } \\
\text { Puanı }\end{array}$ & $\begin{array}{c}\text { Meyve Eti } \\
\text { Sertliği Puanı }\end{array}$ & Kumluluk Puanı & Toplam Puan \\
\hline 44.02 .03 & 90 & 60 & 45 & 30 & 60 & 285 \\
\hline 44.02 .07 & 90 & 40 & 45 & 30 & 60 & 265 \\
\hline 44.02 .15 & 90 & 60 & 45 & 30 & 40 & 265 \\
\hline 44.05 .02 & 90 & 60 & 45 & 30 & 40 & 265 \\
\hline 44.02 .04 & 60 & 60 & 45 & 30 & 60 & 255 \\
\hline 44.02 .05 & 90 & 60 & 30 & 15 & 60 & 255 \\
\hline 44.02 .11 & 90 & 40 & 30 & 30 & 60 & 250 \\
\hline 44.06 .15 & 90 & 40 & 45 & 15 & 60 & 250 \\
\hline 44.07 .07 & 90 & 60 & 30 & 30 & 40 & 250 \\
\hline 44.11 .19 & 90 & 40 & 45 & 30 & 40 & 245 \\
\hline 44.11 .05 & 60 & 60 & 45 & 15 & 60 & 240 \\
\hline 44.11 .04 & 60 & 60 & 45 & 30 & 40 & 235 \\
\hline 44.02 .12 & 30 & 60 & 30 & 45 & 60 & 225 \\
\hline 44.11 .18 & 60 & 40 & 45 & 30 & 40 & 215 \\
\hline 44.02 .06 & 30 & 60 & 30 & 30 & 60 & 210 \\
\hline 44.07 .09 & 60 & 60 & 30 & 15 & 40 & 205 \\
\hline 44.12 .02 & 60 & 40 & 30 & 30 & 40 & 200 \\
\hline 44.06 .01 & 60 & 60 & 30 & 15 & 20 & 185 \\
\hline 44.06 .10 & 30 & 40 & 30 & 30 & 40 & 170 \\
\hline 44.06 .11 & 30 & 20 & 45 & 30 & 40 & 165 \\
\hline
\end{tabular}


Çizelge 7. Ümitvar genotiplerin fiziksel meyve özellikleri

\begin{tabular}{|c|c|c|c|c|c|c|c|c|c|c|}
\hline $\begin{array}{c}\text { Genotip } \\
\text { No }\end{array}$ & $\begin{array}{l}\text { Meyve } \\
\text { Ağırlığı } \\
\text { (g) }\end{array}$ & $\begin{array}{l}\text { Meyve Eni } \\
\quad(\mathrm{mm})\end{array}$ & $\begin{array}{l}\text { Meyve } \\
\text { Boyu } \\
(\mathrm{mm})\end{array}$ & $\begin{array}{l}\text { Meyve } \\
\text { Sap } \\
\text { Uzunluğu } \\
(\mathrm{mm}) \\
\end{array}$ & $\begin{array}{l}\text { Meyve } \\
\text { Sap Çapı } \\
(\mathrm{mm})\end{array}$ & $\begin{array}{l}\text { Meyve Eti } \\
\text { Sertliği } \\
\left(\mathrm{kg} / \mathrm{cm}^{2}\right)\end{array}$ & $\mathrm{L}^{*}$ & $a^{*}$ & $b^{*}$ & $\begin{array}{c}\text { Toplam Tartılı } \\
\text { Derecelendirme } \\
\text { Puanı }\end{array}$ \\
\hline 44.02 .03 & 151.89 & 60.99 & 86.99 & 32.20 & 2.40 & 4.95 & 55.13 & -8.00 & 24.59 & 285 \\
\hline 44.05 .02 & 173.58 & 69.28 & 69.95 & 40.88 & 2.63 & 5.73 & 43.66 & -6.70 & 21.74 & 265 \\
\hline 44.02 .15 & 174.15 & 66.32 & 68.67 & 23.89 & 3.54 & 5.98 & 41.78 & -9.39 & 19.17 & 265 \\
\hline 44.02 .07 & 197.65 & 66.52 & 94.25 & 34.09 & 3.11 & 5.30 & 52.59 & -3.60 & 20.79 & 265 \\
\hline 44.02 .04 & 109.21 & 58.85 & 63.71 & 31.78 & 3.10 & 5.47 & 43.40 & 3.33 & 18.90 & 255 \\
\hline 44.02 .05 & 158.82 & 62.56 & 72.21 & 32.07 & 3.17 & 4.38 & 50.96 & -6.57 & 22.59 & 255 \\
\hline 44.06 .15 & 157.90 & 64.19 & 70.96 & 54.43 & 3.06 & 3.95 & 49.92 & -4.54 & 25.59 & 250 \\
\hline 44.07 .07 & 167.00 & 68.32 & 59.92 & 61.74 & 2.62 & 6.91 & 48.66 & -7.11 & 24.11 & 250 \\
\hline 44.02 .11 & 171.33 & 60.05 & 91.04 & 26.90 & 2.99 & 5.08 & 45.85 & -8.56 & 19.99 & 250 \\
\hline 44.11 .19 & 187.14 & 71.50 & 71.50 & 29.07 & 3.44 & 6.94 & 40.76 & -10.45 & 18.13 & 245 \\
\hline 44.11 .05 & 125.57 & 58.44 & 58.23 & 24.78 & 3.07 & 4.83 & 45.15 & -9.11 & 21.11 & 240 \\
\hline
\end{tabular}

Çizelge 8. Ümitvar genotiplerin kimyasal ve duyusal meyve özellikleri

\begin{tabular}{|c|c|c|c|c|c|c|c|c|}
\hline Genotip No & SCKM (\%) & TEA (\%) & $\begin{array}{c}\text { Meyve Suyu } \\
\text { pH'sl }\end{array}$ & $\begin{array}{l}\text { Meyve Sapı } \\
\text { Şekli }\end{array}$ & $\begin{array}{l}\text { Kumluluk } \\
\text { Durumu }\end{array}$ & $\begin{array}{c}\text { Tat } \\
\text { Durumu }\end{array}$ & $\begin{array}{l}\text { Yeme } \\
\text { Kalitesi }\end{array}$ & $\begin{array}{c}\text { Toplam Tartılı } \\
\text { Derecelendirme } \\
\text { Puanı }\end{array}$ \\
\hline 44.02 .03 & 15.94 & 0.36 & 4.10 & Kıvrık & Kumsuz & İyi & İyi & 285 \\
\hline 44.05 .02 & 16.20 & 0.18 & 4.64 & Kıvrık & Orta Kumlu & Çok İyi & İyi & 265 \\
\hline 44.02 .15 & 15.00 & 0.78 & 3.62 & Düz & Orta Kumlu & Orta & İyi & 265 \\
\hline 44.02 .07 & 13.50 & 0.21 & 4.27 & Eğik & Kumsuz & İyi & İyi & 265 \\
\hline 44.02 .04 & 17.97 & 0.21 & 4.59 & Düz & Kumsuz & İyi & İyi & 255 \\
\hline 44.02 .05 & 17.30 & 0.47 & 3.74 & Eğik & Kumsuz & Orta & Orta & 255 \\
\hline 44.06 .15 & 14.70 & 0.09 & 4.93 & Kıvrık & Kumsuz & İyi & İyi & 250 \\
\hline 44.07 .07 & 17.30 & 0.33 & 3.86 & Eğik & Orta Kumlu & Orta & Orta & 250 \\
\hline 44.02 .11 & 14.15 & 0.36 & 3.93 & Eğik & Kumsuz & Orta & Orta & 250 \\
\hline 44.11 .19 & 13.25 & 0.15 & 4.73 & Eğik & Orta Kumlu & İyi & İyi & 245 \\
\hline 44.11 .05 & 16.37 & 0.29 & 4.57 & Eğik & Kumsuz & İyi & İyi & 240 \\
\hline
\end{tabular}

Ümitvar genotiplerin kimyasal meyve özelliklerinden SÇKM oranı \% 13.25 (44.11.19)17.97 (44.02.04), TEA değeri \% 0.09 ( 44.06.15)0.78 (44.02.15), $\mathrm{pH}$ değeri ise 6.62 (44.02.15)-4.93 (44.06.15) arasında değişmiştir. Ümitvar genotiplerde meyve sapı şeklinin 2 genotipte düz (44.02.04, 44.02.15), 6 genotipte eğik (44.02.07, $44.11 .05,44.11 .19,44.02 .05,44.02 .11,44.07 .07)$ ve 3 genotipte ise kıvrık (44.05.02, 44.02.03, 44.06.15) olduğu belirlenmiştir. Kumluluk durumu bakımından 7 genotip kumsuz $(44.02 .04,44.02 .07$, 44.11.05, 44.02.05, 44.02.11, 44.02.03, 44.06.15), 4 genotip ise orta derecede kumlu $(44.02 .15,44.11 .19$, 44.07.07, 44.05.02) olarak belirlenirken, tat durumunun 1 genotipte çok iyi (44.05.02), 6 genotipte iyi $(44.02 .04,44.02 .07,44.11 .05,44.02 .03$, $44.06 .15,44.11 .19)$ ve 4 genotipte ise orta derecede (44.02.05, 44.02.11, 44.02.15, 44.07.07) olduğu saptanmıştır. Yeme kalitesinin 8 genotipte iyi (44.05.02, 44.02.04, 44.02.07, 44.11.05, 44.02.03, $44.06 .15,44.11 .19,44.02 .15) 3$ genotipte ise orta kalitede (44.02.05, 44.02.11, 44.07.07) olduğu belirlenmiştir (Çizelge 8).

\section{Sonuçlar ve Tartışma}

Malatya ili, ilçeleri ve köylerinde 2014-2017 yılları arasında yürütülen bu çalışmada ön seleksiyonla 20 farklı yerel güzlük armut genotipi belirlenmiştir. Belirlenen ağaçlardan iki yıl süreyle alınan meyve örneklerinde pomolojik ve duyusal analizler gerçekleştirilmiş ve elde edilen veriler tartılı derecelendirme metodu ile değerlendirilmiştir. Yapılan değerlendirmede 240 ve üzeri puan alan 11 genotip (44.02.03, 44.02.07, 44.02.15, 44.05.02, 44.02.04, 44.02.05, 44.02.11, 44.06.15, 44.07.07, 44.11.19, 44.11.04) ümitvar olarak belirlenmiștir.

Ümitvar olarak belirlenen genotiplerde tartılı derecelendirmede esas alınan kriterlerden ortalama meyve ağırlığının 109.21 (44.02.04) - $197.65 \mathrm{~g}$ (44.02.07) arasında değiștiği belirlenmiştir. Orman (2005), Van ili Bahçesaray ilçesinde yürüttüğü çalışmada ümitvar genotiplerde meyve ağırlığının 80.00 - 128.00 g arasında değiștiğini bildirmektedir. Öztürk (2010), Sinop ilinde yürüttüğü çalışmada ümitvar genotiplerde meyve ağırlığının 45.9-479.9 g arasında değiştiğini saptamıştır. Bostan ve Acar (2013), Ünye ve çevresinde yetiştirilen mahalli armutlarda yürüttükleri çalışmada ortalama meyve 
ağırlığının 18.7-258.3 g arasında değiștiğini saptamıştır. Öz ve Aslantaş (2015), Erzincan Bahçe Kültürleri Araştırma İstasyonu koleksiyon parselinde muhafaza edilmekte olan armut genotiplerinde yürüttükleri çalışmada meyve ağırlığının 2010 yılında 34.06-476.41 g, 2011 yılında ise $\quad 30.77-240.76 \mathrm{~g}$ arasında değiştiğini bildirmektedir. Ertaş (2016), Siirt ve çevresinde yetişen mahalli armutlarda yürüttüğü çalışmada çeşitlerin ortalama meyve ağırlığının 27.33-300.26 g arasında değiştiğini saptamıștır. Cevahir ve Bostan (2017), Trabzon ili of ilçesinde yetiştirilen yerel armutlarda yürüttükleri çalışmada ortalama meyve ağırlığının 53.80-151.48 g arasında değiștiğini bildirmektedir. Oturmak ve ark. (2017), Diyarbakır ilinde yürüttükleri çalışmada meyve ağırlığının 39.52-263.12 g arasında değiştiğini saptamıştır. Sağır (2017), Trabzon ilinde yürüttüğü çalışmada mahalli güzlük armutlarda meyve ağırlığının 31.70 $164.75 \mathrm{~g}$ arasında değiştiğini bildirmektedir. Meyve ağırlı̆̆ı bakımından bizim çalışmamızla önceki çalışmalar kıyaslandığında, diğer araştırmacıların daha geniş aralıkta sonuçlar elde ettiği görülmektedir. $\mathrm{Bu}$ durumun çalıșılan materyalin farklılığından ve farklı ekolojik ve bakım koşullarından kaynaklandığı düşünülmektedir.

Çalışmamızda ümitvar bireylerde meyve eti sertliğinin 3.95 (44.06.15)-6.94 kg/ $\mathrm{cm}^{2}$ (44.11.19) arasında değiştiği belirlenmiştir. Armutta yürütülen benzer çalışmalarda meyve eti sertliğini Karlıdağ ve Eşitken (2006), 3.70- $5.25 \mathrm{~kg} / \mathrm{cm}^{2}$, Kılıç ve Bostan (2016), 4.29-9.36 kg/ $\mathrm{cm}^{2}$, Cevahir ve Bostan (2017), 2.81-8.29 kg/cm², Sağır (2017) ise 2.26-8.26 $\mathrm{kg} / \mathrm{cm}^{2}$ arasında değiştiğini saptamıştır. Yürütülen bu çalışmadan elde edilen meyve eti sertliği değerlerinin diğer araștırmacıların bulgularıyla paralellik arz ettiği görülmektedir.

Çalışmamızda ümitvar bireylerde SÇKM oranının \% 13.25 (44.11.19)-17.97 (44.02.04) arasında değiştiği saptanmıştır. Öztürk (2010), Sinop ilinde yürüttüğü çalışmada ümitvar genotiplerde SÇKM değerinin \% 11.0-16.20 arasında değiștiğini saptamıștır. Ünye ve çevresinde yetiştirilen mahalli armutlarda yürütülen çalışmada SÇKM değerinin \% 10.0-15.3 arasında değiştiği bildirilmektedir (Bostan ve Acar, 2013). Ertaş (2016), Siirt yöresi mahalli armutlarında yürüttüğü çalıșmada SÇKM değerinin \% 8.75-14.50, Cevahir ve Bostan (2017), Trabzon ili of ilçesinde yetiştirilen yerel armutlarda yürüttükleri çalışmada SÇKM değerinin \% 10.6-12.95, Oturmak ve ark. (2017), Diyarbakır ilinde yürüttükleri çalışmada
SÇKM oranının \% 10.00-24.90, Sağır (2017) ise Trabzon İlinde yürüttüğü çalışmada güzlük armutlarda SÇKM değerinin \% 8.80-15.20 arasında değiştiğini bildirmektedir. Armutta yapılan çalışmalardan elde edilen sonuçların, bu çalışmadan elde edilen sonuçlarla benzerlik gösterdiği görülmektedir.

Çalışmamızda ümitvar olarak belirlenen 11 genotipten 7'sinin kumsuz (44.02.03, 44.02.07, 44.02.04, 44.02.05, 44.02.11, 44.06.15, 44.11.04) ve 4'ünün (44.02.15, 44.05.02, 44.07.07, 44.11.19) ise orta derecede kumlu olduğu belirlenmiştir. Yeme kalitesi bakımından 8 genotipin $(44.02 .03,44.02 .07$, $44.02 .15,44.05 .02,44.02 .04,44.06 .15,44.11 .19$, 44.11.04) iyi kalitede, 3 genotipin (44.02.05, 44.02.11, 44.07.07) ise orta kalitede olduğu saptanmıştır. Ertaş (2016), Siirt ili ve çevresinde yetiştirtilen 30 adet mahalli armut çeşidinde yaptığ incelemede çeşitlerden 1'ini az kumlu, 2'sini kumsuz, 27'sini ise orta kumlu olarak belirlemiştir. Oturmak ve ark. (2017), Diyarbakır ilinde yürüttükleri çalışmada 32 mahalli armut çeşidinin pomolojik özelliklerinin yanı sıra meyve kabuğu rengi, meyve eti rengi, meyvelerde kumluluk ve tat durumlarını da incelemişlerdir. Çalışmada tüm değerlendirmeler neticesinde tartılı derecelendirme yöntemine göre yüksek puan alan 6 genotip ümitvar olarak belirlenmiştir.

Çalışmamızda incelediğimiz genotiplerin birçoğu çöğürler üzerine aşılı olup, bir kısmı ise tohumdan yetişmiş olan ağaçlardır. Popülasyonu meydana getiren genotipler genellikle farklı meyve bahçeleri içinde sınır ağacı şeklinde, ev bahçelerinde, yol kenarlarında yetişen ve yeterli bakım uygulanmayan ağaçlardan oluşmaktadır. Ağaçların genellikle bakımsız ve meyve bahçeleri içerisinde ev ihtiyacını karşılamak amacıyla yetiştirildiği göz önüne alındığında, incelenen yerel armut genotiplerinin gerçek morfolojik yapılarını ve meyvelerin genetik potansiyellerini tam anlamıyla ortaya koyamadıkları, daha iyi bakım şartları oluşturulduğu takdirde bu genotiplerin daha başarılı sonuçlar verebileceği düşünülmektedir. $\mathrm{Bu}$ çalışma sonunda belirlenen ümitvar genotipler ileride yapılacak daha kapsamlı ıslah çalışmaları için alt yapı oluşturmaktadır. Bu nedenle belirlenen ümitvar genotipler, seleksiyonun ikinci aşamasında materyal olarak kullanılmak ve genetik kaynakların muhafazası amacıyla Kayısı Araștırma Enstitüsü Müdürlüğü armut koleksiyon parseline aktarılmıştır. 


\section{Kaynaklar}

Altan, A., 1989. Laboratuvar Tekniği. Çukurova Üniversitesi, Ziraat Fakültesi, Ders Kitabı No:36, Adana, s. 172.

Așkın, M. A., Oğuz, H. D., 1995. Erciş’te yetiștirilen ümitvar mellaki armut tiplerinde bazı meyve ve ağaç özelliklerinin tespiti üzerine araştırmalar, Türkiye II. Ulusal Bahçe Bitkileri Kongresi, Cilt:1, 84-88.

Bostan, S. Z., Acar, Ş., 2013. Ünye'de (Ordu) yetiştirilen mahalli armut çeşitlerinin pomolojik özellikleri. Akademik Ziraat Dergisi, 1 (2): 97-106.

Bostan, S. Z., 2009. Pomological traits of local apple and pear cultivars and types grown in Trabzon province. Acta Horticulturae, 825: 293-298.

Bostan, S. Z., Şen, S. M.,1991. Van ve çevresinde yetiştirilen mahalli armut çeşitlerinin morfolojik ve pomolojik özellikleri üzerinde araştırmalar. Yüzüncü Yıl Üniversitesi Ziraat Fak. Dergisi, 1 (3): 153-169.

Büyükyılmaz, M., Bulagay, A. N., Burak, M.,1992. Doğu Marmara Bölgesinde yetişen akça armutlarında klon seleksiyonu. Bahçe, 21 (1-2), 61-68.

Büyükyılmaz, M., Bulagay, A. N., Burak, M., 1994. Marmara Bölgesi için ümitvar armut çeşitleri-III. Bahçe, 23 (1-2), 79-92.

Cemeroğlu, B., 1992. Meyve ve Sebze İşleme Endüstrisinde Temel Analiz Metodları. BILTAV Üniversite Kitapları Serisi, Ankara, No: 02-2, s. 381.

Cevahir, G., Bostan, S. Z., 2017. Of (Trabzon) ilçesi yerel armutları: Erkenci ve orta mevsim çeşitleri. Meyve Bilimi 4 (2): 19-25.

Demirsoy, L., Öztürk, A., Serdar, Ü., Duman, E., 2007. Saklı cennet Camili'de yetiştirilen yerel armut çeşitleri, V. Ulusal Bahçe Bitkileri Sempozyumu, 1: 396 - 400.

Ertaş, A., 2016. Siirt ve Çevresinde Yetișen Mahalli Armut Çeşitlerinin (Pyrus communis L.) Fenolojik ve Pomolojik Özellikleri. Siirt Üniversitesi Fen Bilimleri Enstitüsü, Bahçe Bitkileri Ana Bilim Dalı, Yüksek Lisans Tezi, Siirt 98 s.

FAO, 2016. Dünya gıda ve tarım örgütü, Web sayfası: http://www.fao.org), (Erişim Tarihi: 30.01.2018).

Güleryüz, M., 1977. Erzincan'da yetiștirilen bazı önemli elma ve armut çeşitlerinin pomolojileri ile döllenme biyolojileri üzerine araștırmalar. Atatürk Üniversitesi Yayınları, No: 483 Erzurum.

Karlıdağ, H., Eşitken, A., 2006. Yukarı Çoruh vadisinde yetiştirilen elma ve armut çeșitlerinin bazı pomolojik özelliklerinin belirlenmesi. Yüzüncü Yıl Üniv., Ziraat Fakültesi, Tarım Bilimleri Dergisi (J. Agric. Sci.), 6 (2): 93-96.
Kılıç, D., Bostan, S. Z., 2016. Gürgentepe (Ordu) ilçesinde yetiştirilen yerel armut çeşitlerinin meyve ve ağaç özellikleri. Electronic Journal of Vocational Colleges - December / Aralık 2016: 21-32.

Michelson, L. F., Lachman, W. H., Allen, D. D., 1958. The use of the "Weighted-Rankit" method in variety trials. Proceedings of the American Society for Horticultural Science, 71: 334-338.

Orman, E., 2005. Bahçesaray Yöresi Mahalli Armutlarının Pomolojik ve Morfolojik İncelenmesi. Yüzüncü Yıl Üniversitesi Fen Bilimleri Enstitüsü Bahçe Bitkileri Anabilim Dalı, Yüksek Lisans Tezi, Van, 94 s.

Oturmak, İ., Özrenk, K., Çavuşoğlu, Ş., 2017. Diyarbakır (Silvan, Kulp, Hazro) yöresindeki bazı mahalli armut (Pyrus communis L.) gen kaynaklarının belirlenmesi. Uluslararası Tarım ve Yaban Hayatı Bilimleri Dergisi (UTYHBD), 3 (2): 61-67.

Öz, M., Aslantaş, R., 2015. Doğu Anadolu Bölgesi armut genotiplerinin morfolojik Karakterizasyonu. Atatürk Üniv. Ziraat Fak. Derg., 46 (2): 93-106.

Özbek, S., 1947. Türkiye Armut Yetiştiriciliği ve Önemli Armut Çeşitlerimiz, Ankara Yüksek Ziraat Enstitüsü Basımevi, Ankara.

Özbek, S., 1978. Özel Meyvecilik, Çukurova Üniv. Ziraat Fak. Yayın No: 128, Adana, 486 s.

Özçağıran, R., Ünal, A., Özeker, E., İsfendiyaroğlu, M., 2004. Ilıman İklim Meyve Türleri (Yumuşak Çekirdekli Meyveler Cilt-II), Ege Üniv. Zir. Fak. Yay. 556, İzmir.

Öztürk, A., 2010. Sinop İlindeki Armut Genotiplerinin Morfolojik, Pomolojik ve Moleküler Karakterizasyonu, Ondokuz Mayıs Üniversitesi Fen Bilimleri Enstitüsü Bahçe Bitkileri Anabilim Dalı, Doktora Tezi, Samsun, 200 s.

Öztürk, A., Demirsoy L., 2013. Promising pear genotypes from North Anatolia, Turkey: Preliminary Observations. Journal of the American Pomological Society, 67 (4): 217-227.

Sağır, N., 2017. Trabzon İlinde Yetiştirilen Yerel Armut (Pyrus spp.) Çeşitlerinin Bazı Özelliklerinin Belirlenmesi. Ordu Üniversitesi Fen Bilimleri Enstitüsü Bahçe Bitkileri Anabilim Dalı, Yüksek Lisans Tezi, Ordu, $110 \mathrm{~s}$.

Ülkümen, L., 1938. Malatya'nın Mühim Meyve Çeşitleri Üzerinde Morfolojik, Fizyolojik ve Biyolojik Araștırmalar. Yüksek Ziraat Enstitüsü Rektörlüğü, Ankara, sayı 65.

Ünal, A., Saygıll, H., Hepaksoy, S., Can, H. Z., Türküsay, H., 1997. Ege Bölgesinde armut yetiştiriciliği ve seçilen bazı armut çeşitlerinin pomolojik özellikleri, Yumuşak Çekirdekli Meyveler Sempozyumu, 29-35. 